\title{
Differential cytokine gene expression profiles in the three pathological forms of sheep paratuberculosis Jennifer A Smeed ${ }^{1}$, Craig A Watkins², Susan M Rhind ${ }^{3}$ and John Hopkins*1
}

Address: ${ }^{1}$ Centre for Infectious Diseases, Royal (Dick) School of Veterinary Studies, Summerhall, Edinburgh, EH9 1QH, UK, ${ }^{2}$ Moredun Research Institute, International Research Centre, Pentlands Science Park, Penicuik, Midlothian EH26 0PZ, UK and ${ }^{3}$ Division of Veterinary Clinical Studies, Royal (Dick) School of Veterinary Studies, University of Edinburgh, Easter Bush Veterinary Centre, Midlothian EH25 9RG, UK

Email: Jennifer A Smeed - j.a.smeed@sms.ed.ac.uk; Craig A Watkins - craig.watkins@moredun.ac.uk; Susan M Rhind - susan.rhind@ed.ac.uk; John Hopkins* - john.hopkins@ed.ac.uk

* Corresponding author

Published: 14 August 2007

BMC Veterinary Research 2007, 3:18 doi:10.1186/1746-6/48-3-18

This article is available from: http://www.biomedcentral.com/1746-6148/3/18

(C) 2007 Smeed et al; licensee BioMed Central Ltd.

This is an Open Access article distributed under the terms of the Creative Commons Attribution License (http://creativecommons.org/licenses/by/2.0), which permits unrestricted use, distribution, and reproduction in any medium, provided the original work is properly cited.
Received: 16 May 2007

Accepted: 14 August 2007

\begin{abstract}
Background: Johne's disease is a chronic inflammatory disease of the gut caused by infection with Mycobacterium avium subspecies paratuberculosis (MAP). Symptoms include wasting, diarrhoea, loss of condition and eventual death. Three forms of Johne's disease have been described in sheep paucibacillary, multibacillary and asymptomatic. The paucibacillary form is characterized by an inflammatory, Thl-type immune response. The multibacillary form of the disease, which disseminates the infection, is characterized by macrophage infiltration mediated by a Th2-type immune response, and asymptomatic animals have no clinical symptoms or pathology but are infected with MAP. What determines these three forms of the disease is unknown. To further understand these differences, we used real-time RT-PCR to compare the expression of thirteen cytokine and cytokine-related genes in ileal tissue from sheep with the three forms of the disease.

Results: Three pathological forms of sheep paratuberculosis were defined on the basis of histopathology, cytochemistry (Zeihl-Neelsen) and IS900 PCR. Paucibacillary lesions have largely T cell and eosinophil infiltration and are ZN negative; multibacillary lesions have macrophage infiltration and large numbers of acid-fast bacteria. The pauci- and multibacillary forms are linked to the differential expression of IFN $\gamma$ and IL-I0 respectively. In addition the increased levels of the proinflammatory cytokines (IL-I $\beta$ and TNF $\alpha$ ), IL-8, IL-I8 and TRAF-I in both diseased forms is indicative of persistent inflammatory lesions. No changes were seen in IL-I $\alpha$ in any sheep ileum tissues. Asymptomatic animals are IS900+ with normal histology but have significantly decreased levels of IL-18 and increased levels TNF $\alpha$.
\end{abstract}

Conclusion: We have quantified the expression levels of thirteen cytokine and cytokine related genes in three forms of ovine paratuberculosis using real-time PCR analyses and confirm that sheep pauci- and multibacillary disease are linked to type $I$ and type $2 \mathrm{~T}$ cell responses respectively. The expression patterns of other cytokines shows that both disease forms have an inflammatory aetiology but that the central role for IL-I $\alpha$ in bovine paratuberculosis is not seen in the sheep infection. Asymptomatic animals are infected and show no pathology but can be distinguished, in terms of cytokine expression pattern, from uninfected controls. 


\section{Background}

Paratuberculosis (Johne's disease) is a chronic intestinal disease of ruminants caused by the bacterium Mycobacterium avium subspecies paratuberculosis. The disease is responsible for extensive economic losses worldwide related to fatality and loss of productivity $[1,2]$. The route of disease transmission is mainly faecal-oral; and neonates, when not infected congenitally are infected by ingestion of bacteria from infected teats or the pasture transmitted via the dissemination of diarrhoea from infected animals [3]. Consequently the majority of animals within an infected herd or flock become infected [3]. However, in sheep infection can give rise to three different forms of disease with only about $30 \%$ of animals in an infected flock becoming clinically affected. The majority of animals are asymptomatic; they are infected but show no pathology and do not develop clinical disease [4]. The remaining clinically-affected sheep show two distinct forms of the disease. Approximately $30 \%$ of disease cases are affected by the paucibacillary form of Johne's disease; they have very few bacteria and show a T cell infiltration into the gut. About $70 \%$ of cases have the multibacillary form, which is characterized by a high level of bacterial infection and a macrophage and $\mathrm{B}$ cell infiltration into the gut lamina propria. Both the pauci- and multibacillary forms are equally fatal but there is no evidence that the asymptomatic animals ever succumb to disease $[4,5]$.

Johne's disease pathogenesis in cattle may differ from that in sheep as it is presumed that there is disease progression from the asymptomatic to paucibacillary and then to the fatal multibacillary form [6]. However, even in cattle 4$11 \%$ of animals in affected herds are infected but only $2-$ $4 \%$ develop the disease $[7,8]$. Like the two other major mycobacterial diseases, tuberculosis and leprosy, the epidemiology of paratuberculosis suggests a genetic susceptibility [9]. The paucibacillary cases (tuberculoid pathology) tend to have a strong cell-mediated immunity (CMI), high levels of IFN $\gamma$ and IL-2 and low levels of antibody [10-12]; the multibacillary cases (lepromatous pathology) have high antibody and pro-inflammatory cytokine levels and weak CMI $[10,12]$. Little is known about the asymptomatic form although they are positive for bacterial growth, IS900 and specific antibody $[13,14]$.

As with tuberculosis and leprosy it seems clear that the polarization of the immune response is critical to the clinical outcome of the paratuberculosis infection [15-17]. The intestinal tissue damage that results from a Th1 response (paucibacillary disease) is fundamentally different to that caused by a Th2 response, which leads to multibacillary disease and dissemination of infection. The polarization of the immune response is controlled by the differential expression of T cell polarizing cytokines [18] and it seems that there is differential expression of some of these cytokines in Johne's disease [19]. Several studies describe the changes in expression of cytokines in peripheral blood cells in cattle $[20,21]$ and ileal tissue of both sheep $[11,12]$ and cattle [19,21-24]. Burrells el al. (1999) [11] examined IL-2 and IFN $\gamma$ in both pauci- and multibacillary forms but not the asymptomatic animals while Tanaka et al. [19] quantified cytokines in granulomatous lesions during the preclinical stages of disease; all other studies on the target organ concentrated on analysis of the multibacillary form, including all studies on the ileal tissue in cattle.

This study tested the hypothesis that expression levels of a panel of thirteen cytokine and cytokine associated genes would be different at the site of infection in the three forms of sheep paratuberculosis, and that these differences could relate to the observed pathologies. Furthermore, this study also analyses the asymptomatic form of sheep Johne's disease in relation to uninfected control animals.

\section{Results}

\section{Definition of pathological forms}

All animals from the Johne's disease infected flocks were identified as IS900 positive by PCR analysis and therefore judged to be infected with MAP. Three groups of IS900+ animals could be discriminated on the basis of gross pathology, ZN staining and histopathology. The asymptomatic group had no clinical signs or lesions consistent with Johne's disease, at post mortem. Examination of histological sections of the terminal ileum showed normal histology and no evidence of the presence of acid-fast bacteria (ZN-) (Figure 1A-1C). All other sheep showed clinical signs and post mortem lesions consistent with Johne's disease and could be further differentiated into two groups (paucibacillary and multibacillary) on the basis of $\mathrm{ZN}$ staining of histological sections of terminal ileum. The paucibacillary sheep had no detectable $\mathrm{ZN}+$ bacteria (Figure $2 \mathrm{~A}$ ) and showed a mixed inflammatory infiltrate into the lamina propria (Figure 2B) comprising lymphocytes, eosinophils and multinucleate giant cells (arrowed) with fewer macrophages (Figure 2C). The multibacillary sheep had high numbers of $\mathrm{ZN}+$ acid-fast bacteria (Figure 3A), mostly within the cytoplasm of the large numbers of epithelioid macrophages, which distend the lamina propria (Figure 3B and 3C) and result in flattening of the surface mucosa (Figure 3B). A fourth group of unrelated, control sheep were IS900 negative and were judged to be uninfected with MAP.

\section{Gene expression analysis in ileal tissues}

The expression levels of cytokine transcripts in sheep ileum from the three groups of paratuberculosis-infected sheep and in uninfected controls is shown in Table 1 which shows transcript copy number in relation to the 


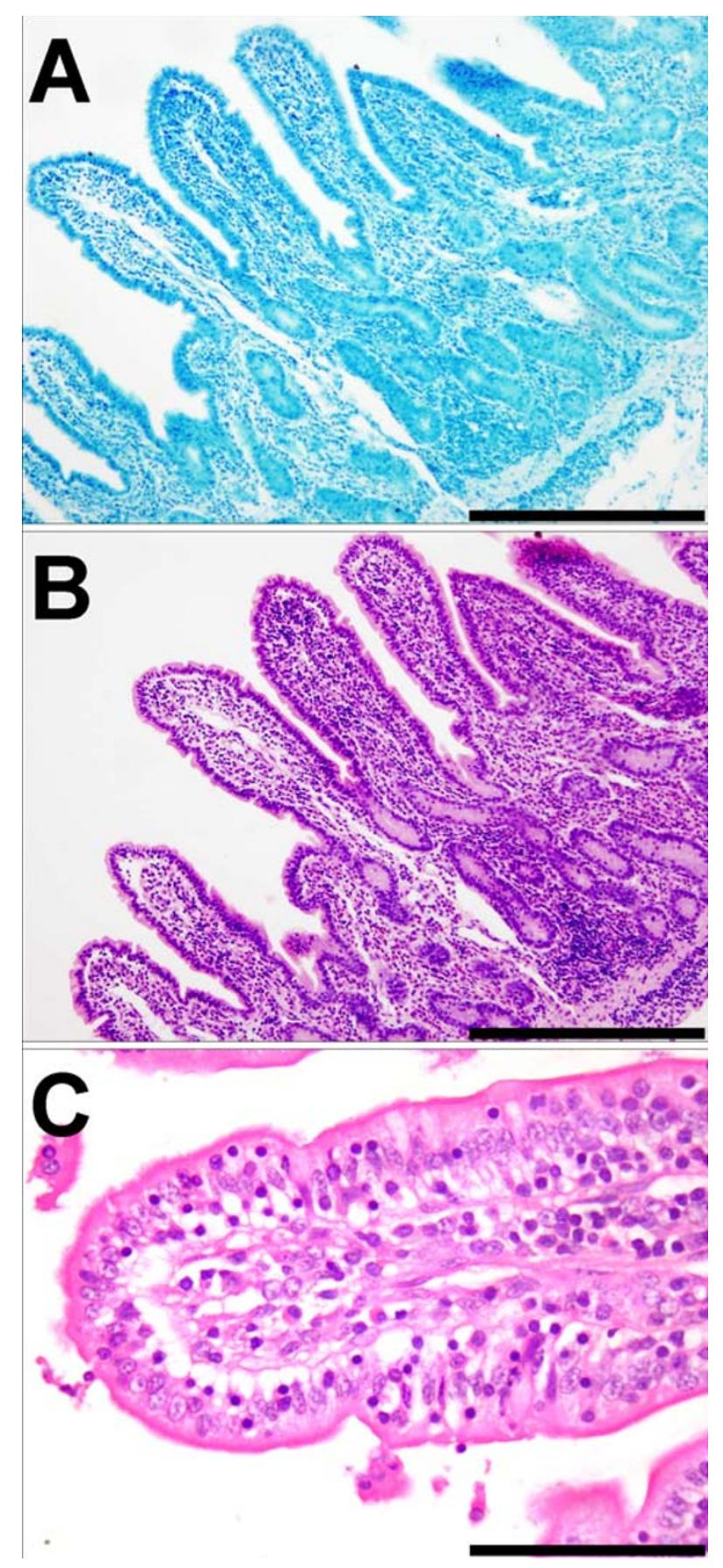

Figure I

Histopathology of the terminal ileum from asymptomatic sheep. (a) Ziehl-Neelsen stain for acid-fast bacteria ( $\times 250$ ) showing the absence of mycobacteria. (b) H\&E stained low power $(\times 250)$ and $(c)$ high power $(\times 400)$ show normal histology.

two housekeeping genes, GAPDH and SDHA. These data show that different cytokines are present at very different levels in ileal tissue, varying from less than 100 copies (e.g. IL-3) to greater than 100,000 copies (e.g. IL-8 and IL10). They also show that levels of individual cytokine transcripts show a high variability between animals, even within the same pathological group.

Furthermore, it shows that individual cytokines are differentially expressed in the distinct disease states.

This is more clearly shown in Figures 4 and 5 where the results are expressed as statistically significant $(\mathrm{p}=0.05)$ fold change where data are compared in six pairs - paucibacillary vs asymptomatic, multibacillary vs asymptomatic, paucibacillary vs multibacillary (Figure 4), paucibacillary vs control, multibacillary vs control and asymptomatic vs control (Figure 5). The expression levels of two genes, IL- $1 \alpha$ and GM-CSF was relatively consistent in all the animals regardless of disease status.

Figure 4 shows the comparison of cytokine transcripts between the three infected groups of sheep. When the two diseased forms were compared with the asymptomatic samples TRAF-1, IL-1 $\beta$, IL-6, IL-18 and IFN $\gamma$ were significantly up-regulated in paucibacillary ileum, (Figure 4a) and TRAF-1, IL-10, IL-18, TNF $\alpha$ and TGF $\beta$ were up-regulated in multibacillary samples (Figure 4b). Comparison of the pauci- and multibacillary forms showed that only IL-10 was significantly different, with the expression levels in the paucibacillary ileum being approximately half that in multibacillary tissue. In contrast the level of IFN $\gamma$ and TRAF-1 were much higher in paucibacillary tissue, however neither was quite significant $(\mathrm{p}=0.057$ and 0.062 respectively). If one outlier point in the TRAF-1 data was removed from the ten samples the significance level was increased to $\mathrm{p}=0.02$ (Figure $4 \mathrm{c}$ ).

Figure 5 shows the comparison of cytokine transcripts between the three infected groups and the uninfected control animals. TRAF-1, IL-8, IL-12p40, IFN $\gamma$, TNF $\alpha$ and TGF $\beta$ were significantly increased in paucibacillary samples (Figure 5a). The multibacillary sheep showed significantly increased levels of TRAF-1, IL-8, IFN $\gamma$, TNF $\alpha$ and TGF $\beta$ (Figure 5b). The multibacillary ileum also showed increased levels of IL-12p40 but this was not quite statistically significant $(p=0.06)$. Interestingly there were significant differences between the asymptomatic and uninfected control samples, which showed that IL-18 was down-regulated and TNF $\alpha$ was up-regulated in the asymptomatic sheep. IL-3 was detected at low levels in all infected animals but never in uninfected control samples; therefore it was not possible to produce fold-change figures for these comparisons. Nevertheless, IL-3 was statistically significantly up-regulated $(\mathrm{p}=0.05)$ in both multibacillary and asymptomatic samples (but not paucibacillary sheep) compared to controls, using the non-parametric Mann-Whitney test. 


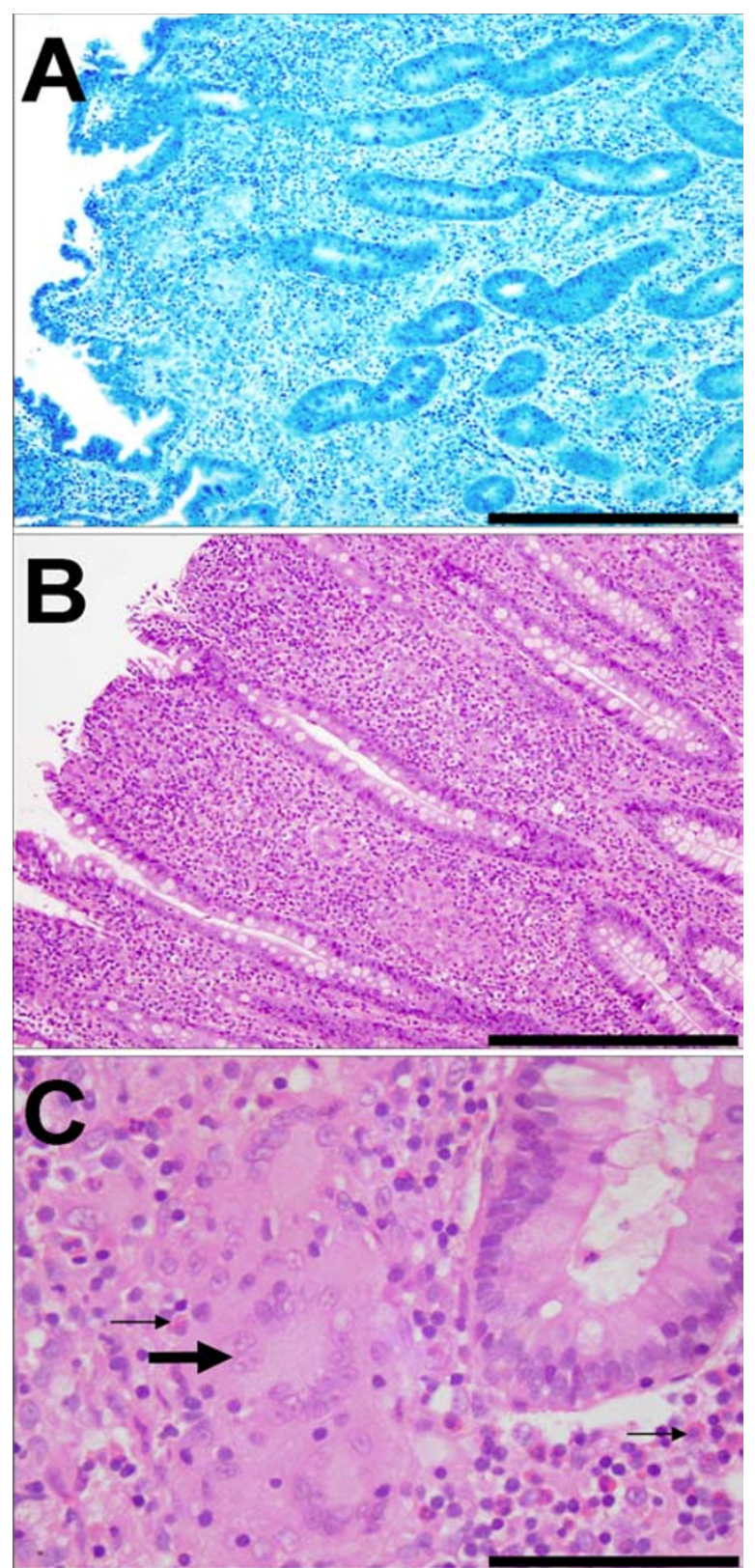

Figure 2

Histopathology of the terminal ileum from paucibacillary sheep. (a) Ziehl-Neelsen stain $(\times 250)$ showing the absence of mycobacteria. (b) H\&E stained low power $(\times 250)$ showing mixed inflammatory infiltrate into lamina propria comprising lymphocytes, eosinophils, macrophages and multinucleate giant cells. (c) H\&E stained high power $(\times 400)$ showing multinucleate giant cells (large arrow) adjacent to a crypt. There is an associated proprial inflammatory reaction dominated by lymphocytes and eosinophils (small arrows).

\section{Discussion}

The three major mycobacterial diseases of mammals tuberculosis, leprosy and paratuberculosis affect different organ systems but share at least two important characteristics. Firstly, not all infected individuals become clinically affected and second, there are at least two pathological forms of each disease $[2,25,26]$. This is most obvious in human leprosy where, although there is a spectrum of disease, the majority of patients are at either end of that spectrum [27]. The tuberculoid form of the disease has lesions formed of infiltrating $\mathrm{T}$ cells and contain few bacteria; and the lepromatous form has lesions of infiltrating macrophages containing large numbers of bacteria $[27,28]$. The pathological picture of ruminant paratuberculosis seems to mimic human leprosy [29] although this is most true of the disease in sheep where the pathology can be differentiated into tuberculoid (paucibacillary), lepromatous (multibacillary) and asymptomatic (infected but no pathology) [1]. There is a difference between these two diseases however as the sheep tuberculoid form is an end stage disease [5] and it is not 'self-curing' as it is in leprosy [27]. There also seem to be differences between ovine and bovine paratuberculosis, as in cattle the pathological form seems to be related to the disease development $[6,29]$, with early stage tuberculoid lesions developing into endstage lepromatous disease. In addition, intermediate stages between these two extremes have also been reported [30,31]. Similar disease patterns are also observed in tuberculosis, but as with bovine paratuberculosis they seem to be more variable than leprosy [32].

Immunological responses to infectious disease challenge have a major bearing on the clinical manifestations of that infection and the clinical consequence for the host. This is most obvious in human leprosy $[33,34]$ where the type 1 $\mathrm{T}$ cell cytokine pattern predominates in the self-curing tuberculoid patients in contrast to the type 2 pattern in malign lepromatous disease. The aim of this present study is to try and understand the relationship between the immunology and the different pathological changes that occur as a result of Mycobacterium avium subspecies paratuberculosis infection in sheep.

Despite the fact that there is a large variation in the levels of cytokine transcript expression, this study shows unambiguously that there is a relationship between the three pathological forms of sheep paratuberculosis and the immune response as represented by the cytokine transcript profiles within the target tissue. The large variation is probably due to the fact that these sheep are unrelated, of different breeds and are infected naturally rather than experimentally; in addition they carry an unquantified gastrointestinal worm burden that might influence ileal cytokine expression. We cannot measure levels of functional protein for all the cytokines within the ileum but 


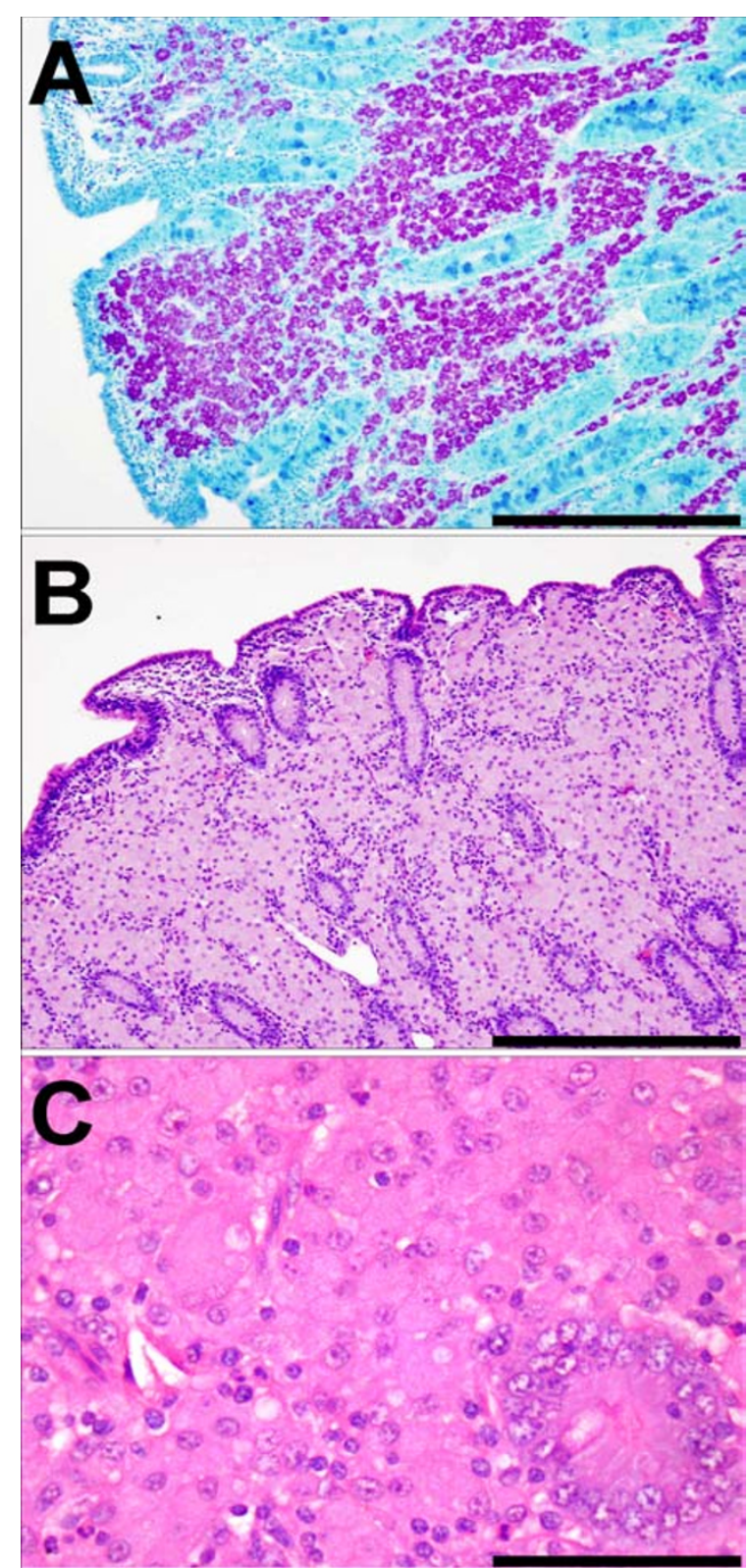

\section{Figure 3}

Histopathology of the terminal ileum from multibacillary sheep. (a) Ziehl-Neelsen stain $(\times 250)$ showing the presence of many intracellular mycobacteria associated with the infiltrating macrophages. (b) H\&E stained low power $(\times 250)$ showing infiltration of the lamina propria by sheets of epithelioid macrophages distending the propria and flattening the surface mucosa. (c) H\&E stained high power $(\times 400)$ demonstrating the uniform population of epithelioid macrophages with abundant cytoplasm infiltrating around an intestinal crypt. (a) PAUCI vS ASYMPTO

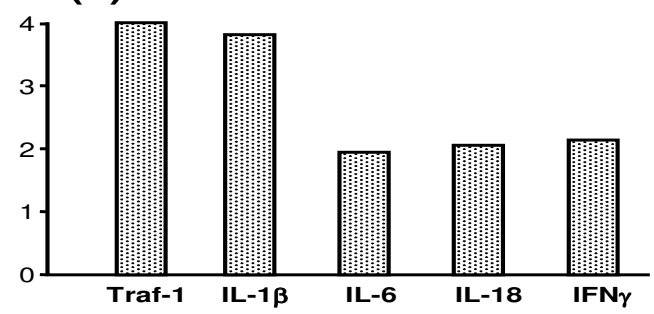

(b)

MULTI vs ASYMPTO

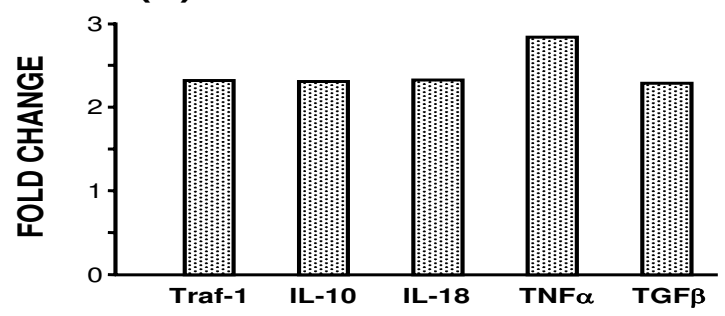

(c)

PAUCI vS MULTI

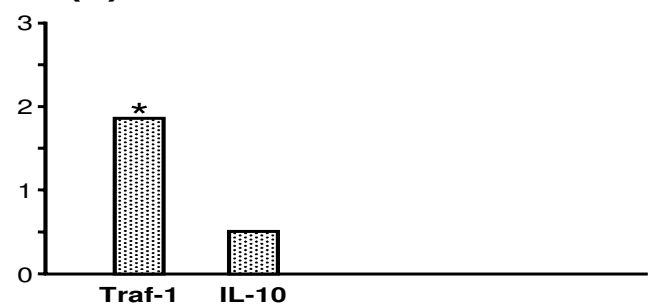

\section{Figure 4}

Statistically significant changes in genes between the three IS900+ groups. (a) Comparison of paucibacillary and asymptomatic; (b) comparison of multibacillary and asymptomatic; (c) comparison of paucibacillary and multibacillary. Results are given as significant $(p \leq 0.05)$ fold-changes of mean copy-numbers relative to the mean copy-numbers of the comparative group. IL-3 was not included, as the copy number in the control samples was 0 , thus fold change values could not be calculated. The data for TRAF-I, highlighted with * in (c) excludes a single outlier in the ten data points; $\mathrm{P}$ $=0.062$ with the outlier; $p \leq 0.02$ without the outlier.

assume that the relative quantities of cytokine protein and transcript are linked.

As has been shown with bovine paratuberculosis [19-21], the paucibacillary and multibacillary forms of the sheep disease are also associated with the polarization of the immune response. The comparison of each form of the disease with tissue from asymptomatic animals shows that IFN $\gamma$ is significantly increased in the paucibacillary lesions and IL-10 is raised in the multibacillary form. Furthermore, direct comparison of the diseased tissues shows that these two cytokines are reciprocally expressed, 
Table I: Cytokine transcript levels in terminal ileum from sheep with paratuberculosis infected sheep and controls

\begin{tabular}{|c|c|c|c|c|}
\hline Gene & Multibacillary & Paucibacillary & Asymptomatic & Control \\
\hline IL-I $\alpha$ & $69^{1} \pm 56$ & $38 \pm 14$ & $51 \pm 42$ & $20 \pm 8$ \\
\hline IL-I $\beta$ & $30839 \pm 41353$ & $16470 \pm 8559$ & $4176 \pm 2557$ & $8613 \pm 6090$ \\
\hline IL-3 & $29 \pm 74$ & $1 \pm 3$ & $87 \pm|3|$ & $0 \pm 0$ \\
\hline IL-6 & $71778 \pm 124310$ & $11023 \pm 2980$ & $4996 \pm 1698$ & $5473 \pm 7583$ \\
\hline IL-8 & $1448098 \pm 1453346$ & $609805 \pm 511880$ & $480573 \pm 601312$ & $150388 \pm 59472$ \\
\hline IL-I0 & $305964 \pm 127868$ & $174186 \pm 82536$ & $12694 \mid \pm 94659$ & $240619 \pm 185599$ \\
\hline IL-I 2 & $7178 \pm 7381$ & $7589 \pm 6467$ & $4506 \pm 5179$ & $1615 \pm 2436$ \\
\hline IL-I8 & $102838 \pm 45|6|$ & $84037 \pm 34888$ & $42352 \pm 10066$ & $|26047 \pm 4| 77 \mid$ \\
\hline GM-CSF & $2512 \pm 1067$ & $2973 \pm 963$ & $1786 \pm 684$ & $1986 \pm 552$ \\
\hline $\mathrm{IFN} \gamma$ & $3354 \pm 1063$ & $5209 \pm 2554$ & $2529 \pm 1620$ & $1537 \pm 427$ \\
\hline TGF- $\beta$ & $50349 \pm 30161$ & $28007 \pm 13809$ & $21871 \pm 11222$ & $14519 \pm 6032$ \\
\hline TNF $\alpha$ & $21113 \pm 13334$ & $1|68| \pm 7914$ & $7492 \pm 4925$ & $2770 \pm 2120$ \\
\hline TRAF-I & $11504 \pm 6076$ & $20087 \pm 10563$ & $5018 \pm 5134$ & $3708 \pm 1662$ \\
\hline
\end{tabular}

'Copy number \pm SD, normalized to SDHA and GAPDH

Table 2: Breed, age and sex of sheep

\begin{tabular}{|c|c|c|c|}
\hline Disease Type & Sheep Breed & Age (years) & Sex \\
\hline Multibacillary & Blackface $\times$ Bleu du Maine & 4.5 & $\mathrm{~F}$ \\
\hline Multibacillary & Blackface $\times$ Bleu du Maine & 4.5 & $\mathrm{~F}$ \\
\hline Multibacillary & Blackface & 5 & $\mathrm{~F}$ \\
\hline Multibacillary & Blackface & 5 & $\mathrm{~F}$ \\
\hline Multibacillary & Blackface & 3 & $\mathrm{~F}$ \\
\hline Multibacillary & Blackface & 3 & $\mathrm{~F}$ \\
\hline Multibacillary & Blackface & 2 & $\mathrm{~F}$ \\
\hline Multibacillary & Blackface & 4 & $\mathrm{~F}$ \\
\hline Multibacillary & Blackface & 4 & $\mathrm{~F}$ \\
\hline Multibacillary & Blackface & 3 & $\mathrm{~F}$ \\
\hline Paucibacillary & Blackface $\times$ Bleu du Maine & 4.5 & $\mathrm{~F}$ \\
\hline Paucibacillary & Texel & 5.5 & $\mathrm{~F}$ \\
\hline Paucibacillary & Blackface $\times$ Bleu du Maine $\times$ Lleyn $\times$ Roussin & 2.5 & $\mathrm{~F}$ \\
\hline Paucibacillary & Lleyn $\times$ Roussin & 3.5 & $\mathrm{~F}$ \\
\hline Paucibacillary & Blackface $\times$ Bleu du Maine & 4.5 & $\mathrm{~F}$ \\
\hline Paucibacillary & Blackface $\times$ Bleu du Maine & 4.5 & $\mathrm{~F}$ \\
\hline Paucibacillary & Bleu du Maine & 4 & $\mathrm{~F}$ \\
\hline Paucibacillary & Blackface $\times$ Bleu du Maine & 6 & $\mathrm{~F}$ \\
\hline Paucibacillary & Texel & 2.5 & $\mathrm{~F}$ \\
\hline Paucibacillary & Blackface & 2.5 & $\mathrm{~F}$ \\
\hline Asymptomatic & Blackface $\times$ Bleu du Maine & 4.5 & $\mathrm{~F}$ \\
\hline Asymptomatic & Blackface $\times$ Bleu du Maine & 4.5 & $\mathrm{~F}$ \\
\hline Asymptomatic & Blackface $\times$ Bleu du Maine & 7 & $\mathrm{~F}$ \\
\hline Asymptomatic & Blackface $\times$ Bleu du Maine & 7 & $\mathrm{~F}$ \\
\hline Asymptomatic & Texel & I & $\mathrm{F}$ \\
\hline Asymptomatic & Blackface & 2.5 & $\mathrm{~F}$ \\
\hline Asymptomatic & Greyface & 3 & $\mathrm{~F}$ \\
\hline Asymptomatic & Greyface & 3 & $\mathrm{~F}$ \\
\hline Asymptomatic & Greyface & 3 & $\mathrm{~F}$ \\
\hline Asymptomatic & Greyface & 3 & $\mathrm{~F}$ \\
\hline
\end{tabular}

The uninfected controls were: 6 Blackface $(F)$ aged 4 years, 3 Texel $(F)$ aged 4/5 years. 
(a)

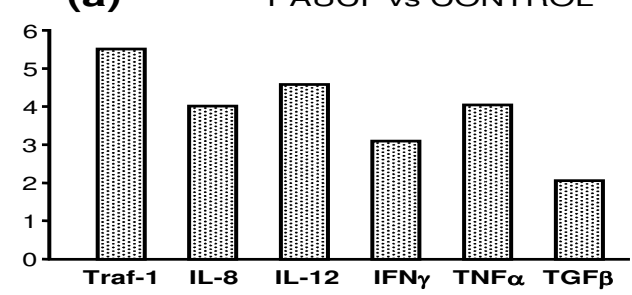

(b)

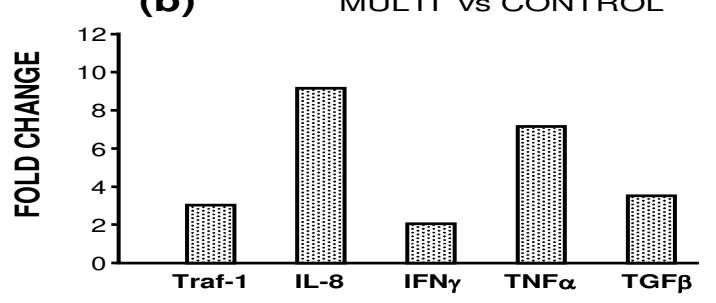

(c)

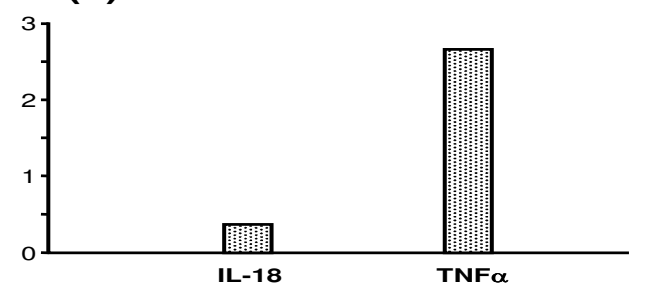

\section{Figure 5}

Statistically significant changes in genes between the three IS900+ groups and the uninfected control group. (a) Comparison of paucibacillary and control; (b) comparison of multibacillary and control; (c) comparison of asymptomatic and control. Results are given as significant ( $\mathrm{P}$ $\leq 0.05$ ) fold-changes of mean copy-numbers relative to the mean copy-numbers of the comparative group.

although the increase (x1.55 fold) of IFN $\gamma$ in paucibacillary ileum is not quite significant ( $p=0.057)$. This confirms that in sheep paratuberculosis polarized type 1 and type $2 \mathrm{~T}$ cells are strongly associated to paucibacillary and multibacillary pathology respectively. The major biological function of IL-18 seems to be linked to inducing type 1 responses and stimulating IFN $\gamma$ production [35]. However, the pattern of IL-18 expression is not explained simply in terms of type 1 and type 2 responses as it is upregulated in both disease forms. Perhaps the increased TGF $\beta$ level in the multibacillary ileum explains the low IFN $\gamma$ levels in that tissue [36].

Comparison of both disease forms to uninfected control samples shows up-regulation of TRAF-1, IL-8, IFN $\gamma$, and $\mathrm{TNF} \alpha$, reflecting the high levels of inflammation present in the affected tissues and agrees with the data in cattle $[21,24]$. TRAF-1 is anti-apoptotic and its up-regulation in both disease forms indicates that it may be associated with the accumulation of several different cell types in the lamina propria and not just macrophages [24]. Previous studies in stimulated PBMC from infected cattle have shown down-regulation of IL-12p35 in infected cattle compared to controls [21]. However, this study showed significant $(\mathrm{p}=0.05)$ up-regulation of IL-12p40 in paucibacillary samples ( $\mathrm{p}=0.06$ for multibacillary tissue). This may be explained by differences in the tissues tested or that IL12 p40 levels reflect IL-23 and not IL-12p70. IL-1 $\beta$ and IL6 were also significantly raised in paucibacillary ileum compared to asymptomatic samples, the increase in multibacillary samples was large but without statistical significance $(\mathrm{p}=0.12)$. Both have been shown previously to be up-regulated in multibacillary disease [37], but as with IL- 8 and TNF $\alpha$ they are also associated with general inflammation. Unlike other gastrointestinal inflammatory lesions [38], the expression of large quantities of proinflammatory cytokines in paratuberculosis is not reflected in the large scale infiltration of neutrophils. A possible explanation for this is the presence of increased levels of TGF $\beta$, which has known anti-inflammatory and immunosuppressive functions [36]. IL-3 is absent from uninfected ileum but can be detected in both asymptomatic and multibacillary tissues; however, the low levels of transcripts present leave doubt about its biological relevance. Our data only partly fit with the 'Coussens' model of bovine paratuberculosis pathogenesis [39]. They are almost identical in relation to the $\mathrm{T}$ cell polarizing cytokines and most of the inflammatory mediators but contrasts in relation to IL- $1 \alpha$. This cytokine is highly upregulated in infected bovine tissue and the model hypothesises that the pathogenesis of paratuberculosis may be partly due to IL-1 $\alpha$ toxicity. However our data show that IL-1 $\alpha$ is virtually absent from sheep ileum. Apart from species differences a possible explanation for this discrepancy is that all the sheep paratuberculosis tissues originate from terminal disease states and not during the development of the pathology.

Of particular interest is the comparison between the infected, asymptomatic and the uninfected, control sheep. Unlike cattle, where asymptomatic animals are regarded as 'preclinical' and show histological lesions [19], asymptomatic sheep show completely normal ileal histology and their susceptibility to disease has been questioned [4]. The normality of the asymptomatic cases is largely confirmed by the fact that the majority of cytokines are expressed at 'normal' levels; however TNF $\alpha$ and IL-18 are exceptions, TNF $\alpha$ is significantly up-regulated and IL-18 is down-regulated in asymptomatic samples. The low levels of IL-18 are not matched by a similar down-regulation of IFN $\gamma$. 
Table 3: Primer sequences used for real time RT- PCR

\begin{tabular}{|c|c|c|}
\hline Gene Accession number & Primer Sequence 5'-3' & $\begin{array}{l}\text { Product } \\
\text { size } \\
\text { (bp) }\end{array}$ \\
\hline $\begin{array}{l}\text { IL-I } \alpha \\
\text { GenBank: NM } 174092\end{array}$ & $\begin{array}{l}\text { F: TTGGTGCACATGGCAAGTG } \\
\text { R: GCACAGTCAAGGCTATTTTTCC }\end{array}$ & 72 \\
\hline $\begin{array}{l}\text { IL-I } \beta \\
\text { GenBank: X56972 }\end{array}$ & $\begin{array}{l}\text { F: CCTTGGGTATCAGGGACAA } \\
\text { R: TGCGTATGGCTTTCTTTAGG }\end{array}$ & 317 \\
\hline $\begin{array}{l}\text { IL-3 } \\
\text { GenBank: ZI8897 }\end{array}$ & $\begin{array}{l}\text { F: ACCTCCTTCTGCTCCTGCTT } \\
\text { R: TATTCCCAAGTCCCCATCTT }\end{array}$ & 193 \\
\hline $\begin{array}{l}\text { IL-6 } \\
\text { GenBank: } \underline{\text { X68723 }}\end{array}$ & $\begin{array}{l}\text { F: TCCAGAACGAGTTTGAGG } \\
\text { R: CATCCGAATAGCTCTCAG }\end{array}$ & 236 \\
\hline $\begin{array}{l}\text { IL-8 } \\
\text { GenBank: X78306 }\end{array}$ & $\begin{array}{l}\text { F: ATGAGTACAGAACTTCGA } \\
\text { R: TCATGGATCTTGCTTCTC }\end{array}$ & 222 \\
\hline $\begin{array}{l}\text { IL-10 } \\
\text { GenBank: U||42| }\end{array}$ & $\begin{array}{l}\text { F: CTGTTGACCCAGTCTCTGCT } \\
\text { R: ACCGCCTTTGCTCTTGTTT }\end{array}$ & 305 \\
\hline $\begin{array}{l}\text { IL-I } 2 p 40 \\
\text { GenBank: AF004024 }\end{array}$ & $\begin{array}{l}\text { F: TCAGACCAGAGCAGTGAGGT } \\
\text { R: GCAGGTGAAGTGTCCAGAAT }\end{array}$ & 243 \\
\hline $\begin{array}{l}\text { IL- } 18 \\
\text { GenBank: AJ40I033 }\end{array}$ & $\begin{array}{l}\text { F: GAGCACAGGCATAAAGATGG } \\
\text { R: TGAACAGTCAGAATCAGGCATA }\end{array}$ & 241 \\
\hline $\begin{array}{l}\text { IFN } \gamma q \\
\text { GenBank: X52640 }\end{array}$ & $\begin{array}{l}\text { F: CTAAGGGTGGGCCTCTTTTC } \\
\text { R: CATCCACCGGAATTTGAATC }\end{array}$ & 55 \\
\hline $\begin{array}{l}\text { TNF } \alpha \\
\text { GenBank: } \underline{\text { X56756 }}\end{array}$ & $\begin{array}{l}\text { F: GAATACCTGGACTATGCCGA } \\
\text { R: CCTCACTTCCCTACATCCCT }\end{array}$ & 238 \\
\hline $\begin{array}{l}\text { TGF } \beta \\
\text { GenBank: } \underline{X 76916}\end{array}$ & $\begin{array}{l}\text { F: GAACTGCTGTGTTCGTCAGC } \\
\text { R: GGTTGTGCTGGTTGTACAGG }\end{array}$ & 169 \\
\hline $\begin{array}{l}\text { GM-CSF } \\
\text { GenBank: X53561 }\end{array}$ & $\begin{array}{l}\text { F: GATGGATGAAACAGTAGAAGTCG } \\
\text { R: CAGCAGTCAAAGGGAATGAT }\end{array}$ & 261 \\
\hline $\begin{array}{l}\text { TRAFI } \\
\text { GenBank: } \underline{X M \quad 589090}\end{array}$ & $\begin{array}{l}\text { F: AGCAGAGGGTGTTGGAGTTG } \\
\text { R: CTGGGGAGAAGAGGCTGAC }\end{array}$ & 186 \\
\hline $\begin{array}{l}\text { GAPDH } \\
\text { GenBank: AF030943 }\end{array}$ & $\begin{array}{l}\text { F: GGTGATGCTGGTGCTGAGTA } \\
\text { R: TCATAAGTCCСTCCACGATG }\end{array}$ & 265 \\
\hline $\begin{array}{l}\text { SDHA } \\
\text { GenBank: NM } 174178\end{array}$ & $\begin{array}{l}\text { F: ACCTGATGCTTTGTGCTCTGC } \\
\text { R: CCTGGATGGGCTTGGAGTAA }\end{array}$ & 126 \\
\hline
\end{tabular}

\section{Conclusion}

In this study, we have quantified the expression levels of thirteen important immunoregulatory genes in the three forms of ovine paratuberculosis using real-time RT-PCR analyses. We have confirmed that the paucibacillary and multibacillary pathologies are linked to type 1 and type 2 $\mathrm{T}$ cell responses respectively. However, many other cytokines are differentially expressed and it is clear that these cytokines are part of a complex network and interact to form the final pathologies. It is also clear that asymptomatic animals are also responding to infection, although the data do not explain how the disease is controlled in these animals. The epidemiology of the disease would suggest a genetic susceptibility similar to that recognised for tuberculosis and leprosy, and these data suggest several likely candidates for future genetic analysis.

\section{Methods}

All procedures involving animals was approved by the Home Office under the appropriate Animals (Scientific Procedures) Act 1986 Project Licence.

\section{Experimental animals/tissues}

Animals with the clinical disease and asymptomatic animals were out bred sheep with naturally acquired MAP infection from one of three farms (Table 2). Individual sheep were delivered to the Moredun Research Institute based on clinical symptoms of Johne's disease. All sheep were euthanized and the diagnosis of Johne's disease was confirmed by histopathology of the terminal ileum and IS900 real-time PCR. Sheep from the same flocks with no clinical signs of Johne's disease but that were positive for IS900 were considered to be asymptomatic [4]. All control sheep tested negative for IS900. There were ten animals in each of the infected group and nine uninfected controls. Terminal ileum samples for histopathology were removed post-mortem and fixed in $10 \%$ formol-saline. Four $\mu \mathrm{m}$ sections from paraffin wax-embedded tissue were stained with haematoxylin and eosin or Ziehl-Neelsen (ZN). For RNA preparations, tissue blocks $(\sim 0.5 \mathrm{~g})$ were placed in five volumes of in RNAlater (Ambion, Huntingdon, UK), which were then incubated overnight at $4{ }^{\circ} \mathrm{C}$ and then stored at $-80^{\circ} \mathrm{C}$. 


\section{IS900 quantitative PCR}

All RNA samples were tested for the presence of MAP by IS900 real-time RT-PCR for a MAP specific insertion sequence [40]. Primers and probes were as Eishi et al. [41], and the reactions were carried out in an ABI Prism 7000 real-time PCR machine. Each reaction contained $12.5 \mu$ l Platinum ${ }^{\otimes}$ Quantitative PCR SuperMix-UDG with ROX (Invitrogen; Paisley, UK), $50 \mathrm{nM}$ each primer, 100 $\mathrm{nM}$ probe and $5 \mu \mathrm{l} \mathrm{cDNA}$, made up to $25 \mu \mathrm{l}$ with deionised water. The reactions were cycled as follows: $50^{\circ} \mathrm{C}$ for 2 minutes, $95^{\circ} \mathrm{C}$ for 10 minutes and 40 cycles of $95^{\circ} \mathrm{C}$ for 15 seconds, then $60^{\circ} \mathrm{C}$ for 1 minute.

\section{Isolation RNA Isolation and CDNA synthesis}

Tissue samples were thawed at room temperature, $250 \mathrm{mg}$ wet weight of ileum tissue was shredded and then disrupted and homogenised in a buffer containing $4 \mathrm{M}$ guanidine isothiocyanate using a ribolyser (Fast-Prep from Thermo-Hybaid, Runcorn, UK). Total RNA was extracted using a Qiagen RNeasy ${ }^{\circledast}$ Maxi Kit (Qiagen, Crawley, UK) and DNase treated using the Ambion DNase I kit (Ambion, Huntingdon, UK). Samples were eluted into $800 \mu \mathrm{l}$ of nuclease-free water. The RNA was quantified by spectrophotometry, ethanol precipitation and resuspended in $300 \mu \mathrm{l}$ of nuclease-free water. Samples were checked for genomic DNA contamination by GAPDH PCR.

For cDNA synthesis, $2.5 \mu \mathrm{g}$ of RNA was diluted to a final volume of $16.25 \mu \mathrm{l}$ in nuclease free water. $500 \mathrm{ng}$ of Oligo (dT) (Promega, Southampton, UK) was added, and incubated for five minutes at $70^{\circ} \mathrm{C}$, followed by five minutes on ice. To this $5 \mu \mathrm{l}$ of $5 \times$ MMLV buffer, $1.25 \mu \mathrm{l}$ of $100 \mathrm{mM}$ dNTPs and $1 \mu \mathrm{l}$ of MMLV RT enzyme (Promega) were added, and the mixture was incubated at $42^{\circ} \mathrm{C}$ for $60 \mathrm{~min}$ utes, followed by 15 minutes at $70^{\circ} \mathrm{C}$ to inactivate the enzyme. The cDNA was diluted four-fold in nuclease free water and stored at $-20^{\circ} \mathrm{C}$ until used.

\section{Cloning of ovine cytokine gene fragments}

Primers (Table 3) were selected and designed using Primer3 [42] software. All selected primer sequences were then checked for possible cross-hybridization using the BLAST [43] and subjected to quality check using Net Primer [44]. The PCR mixture contained $2 \mu$ of cDNA; 5 $\mu \mathrm{l}(10 \times)$ PCR buffer (Promega); $1 \mu \mathrm{l}$ dNTP mix (Promega); 20 pmol of each primer (Sigma-Genosys, Haverhill, UK); $1 \mu \mathrm{l} \mathrm{Taq} \mathrm{polymerase} \mathrm{(5} \mathrm{units)} \mathrm{and} \mathrm{nuclease} \mathrm{free} \mathrm{water}$ was added to a final volume of $50 \mu \mathrm{l}$. Reactions were then cycled under the following conditions: $95^{\circ} \mathrm{C}$ for 2 mins 30 cycles of $30 \mathrm{~s}$ at $95^{\circ} \mathrm{C}$, annealing at (see Table 1), $45 \mathrm{~s}$; $60 \mathrm{~s}$ at $72^{\circ} \mathrm{C}$, followed by a final extension at $72^{\circ} \mathrm{C}$ for 5 mins. PCR products were analysed by agarose gel electrophoresis, visualized by ethidium bromide/UV transillu- mination, purified using the QIAquick ${ }^{\circledR}$ system (Qiagen), cloned into pGEM T-Easy ${ }^{\circledR}$ (Promega) and sequenced.

\section{Quantitative real-time PCR}

Two-step, quantitative real-time RT-PCR was carried out using a Rotor-Gene 3000 (Corbett Life Science, Cambridge, UK) using primers as in Table 3. Standard curves for each gene were generated using 10-fold serial dilution series of linearized plasmid DNA templates. Quantitative real-time PCR reactions were run in $20 \mu$ l containing $2 \mu \mathrm{l}$ of FastStart Taq buffer, $200 \mu \mathrm{M}$ dNTPs (Promega), 250 $\mathrm{nM}$ each primer, $\mathrm{MgCl} 2$ to an optimum concentration, $0.7 \mu \mathrm{l}$ of a $1 / 1000$ dilution of SYBR green master mix, 0.75 U FastStart Taq DNA Polymerase(all Roche Diagnostics, Lewes, UK) and $2 \mu \mathrm{l}$ of template cDNA, made up to $20 \mu \mathrm{l}$ with deionised water. The cycling conditions for all genes were as follows: 5 minutes at $94^{\circ} \mathrm{C}, 45$ cycles of $20 \mathrm{sec}-$ onds at $94^{\circ} \mathrm{C}, 20$ seconds at $60^{\circ} \mathrm{C}$ and 20 seconds at $72^{\circ} \mathrm{C}$, followed by a melt curve starting at $65^{\circ} \mathrm{C}$ rising to $94^{\circ} \mathrm{C}$ at $0.3^{\circ} \mathrm{C}$ per second. Copy numbers were determined from the $\mathrm{Ct}$ values of each sample in comparison to the copy number values assigned from the plasmid DNA standard using Rotor-Gene analysis software (6.0.34). Data were normalized using glyceraldehyde-3phosphate dehydrogenase (GAPDH) or succinate dehydrogenase (SDHA) housekeeping genes. A normalization factor was calculated taking into account the 75th percentile of the housekeeping gene copy numbers for each run. Results were compared pair wise using a 2-sample t test to determine statistical significance. Each sample was analysed in duplicate, $\mathrm{n}=10$ for each IS900+ sheep and $\mathrm{n}=9$ for the uninfected controls.

\section{Variability assay}

To determine the level of variability inherent in the realtime PCR reactions, a variability assay was carried out. A single sample was reverse transcribed in three simultaneous reactions. The cDNA produced was then amplified ten times each in an SDHA real-time PCR reaction. The resulting copy numbers were compared to give a value for the variability inherent within the reactions. The assay showed that the overall variability inherent to the method is 2.2 fold.

\section{Competing interests}

The authors declare that they have no competing interests.

\section{Authors' contributions}

JAS performed the real-time PCR experiments and was responsible for the draft manuscript preparation. CAW supervised JAS in the practical work; he performed the post-mortems and helped JAS with data analysis and draft manuscript preparation. SMR performed the histopathological diagnosis and analysis. JH was in overall control of 
the project and was responsible for its design, coordination and funding; he produced the final manuscript.

\section{Acknowledgements}

We would like to acknowledge Dr Anton Gossner, Dr Katie Matthews, Dr Tom McNeilly and Sofia Roupaka in the Centre for Infectious Diseases, University of Edinburgh, for supplying primers and cloned plasmids. This Project was funded by BBSRC Grant I5/SI3964. JAS is funded by BBSRC/ Genesis-Faraday CASE studentship and sponsored by Moredun Scientific Ltd. Midlothian, UK

\section{References}

I. Clarke C], Little D: The pathology of ovine paratuberculosis: gross and histological changes in the intestine and other tissues. J Comp Pathol 1996, I I 4:4 I9-437.

2. Gonda MG, Chang YM, Shook GE, Collins MT, Kirkpatrick BW: Effect of Mycobacterium paratuberculosis infection on production, reproduction, and health traits in US Holsteins. Prev Vet Med 2007.

3. van Roermund HJ, Bakker D, Willemsen PT, de Jong MC: Horizontal transmission of Mycobacterium avium subsp. paratuberculosis in cattle in an experimental setting: Calves can transmit the infection to other calves. Vet Microbiol 2007.

4. Begara-McGorum I, Wildblood LA, Clarke C], Connor KM, Stevenson K, Mclnnes CJ, Sharp JM, Jones DG: Early immunopathological events in experimental ovine paratuberculosis. Vet Immunol Immunopathol 1998, 63:265-287.

5. Clarke C): The pathology and pathogenesis of paratuberculosis in ruminants and other species. I Comp Pathol 1997, I |6:217-26I.

6. Stabel JR: Transitions in immune responses to Mycobacterium paratuberculosis. Vet Microbiol 2000, 77:465-473.

7. Withers FW: Incidence of the disease. The Veterinary Record 1959, 71:1150-1153

8. Cetinkaya B, Egan K, Harbour DA, Morgan KL: An abattoir-based study of the prevalence of subclinical Johne's disease in adult cattle in south west England. Epidemiol Infect 1996, I I 6:373-379.

9. Bleharski JR, Li H, Meinken C, Graeber TG, Ochoa MT, Yamamura M, Burdick A, Sarno EN, Wagner M, R $\div$ llinghoff M, Rea TH, Colonna M, Stenger S, Bloom BR, Eisenberg D, Modlin RL: Use of genetic profiling in leprosy to discriminate clinical forms of the disease. Science 2003, 301: 1527-1530.

10. Burrells C, Clarke C], Colston A, Kay JM, Porter J, Little D, Sharp JM: A study of immunological responses of sheep clinicallyaffected with paratuberculosis (Johne's disease). The relationship of blood, mesenteric lymph node and intestinal lymphocyte responses to gross and microscopic pathology. Vet Immunol Immunopathol 1998, 66:343-358.

II. Burrells C, Clarke CJ, Colston A, Kay JM, Porter J, Little D, Sharp JM: Interferon-gamma and interleukin-2 release by lymphocytes derived from the blood, mesenteric lymph nodes and intestines of normal sheep and those affected with paratuberculosis (Johne's disease). Vet Immunol Immunopathol 1999, 68:139-148.

12. Alzuherri HM, Woodall CJ, Clarke CJ: Increased intestinal TNFalpha, IL-I beta and IL- 6 expression in ovine paratuberculosis. Vet Immunol Immunopathol 1996, 49:33 I-345.

13. Carrigan MJ, Seaman JT: The pathology of Johne's disease in sheep. Aust Vet J 1990, 67:47-50.

14. Sweeney RW, Whitlock RH, Rosenberger AE: Mycobacterium paratuberculosis isolated from fetuses of infected cows not manifesting signs of the disease. Am J Vet Res 1992, 53:477-480.

15. Koets A, Rutten V, Hoek A, van Mil F, Mller K, Bakker D, Gruys E, van Eden W: Progressive bovine paratuberculosis is associated with local loss of CD4(+) T cells, increased frequency of gamma delta $T$ cells, and related changes in T-cell function. Infect Immun 2002, 70:3856-3864.

16. Yamamura M, Uyemura K, Deans RJ, Weinberg K, Rea TH, Bloom BR Modlin RL: Defining protective responses to pathogens: cytokine profiles in leprosy lesions. Science 199|, 254:277-279.

17. Barnes PF, Lu S, Abrams JS, Wang E, Yamamura M, Modlin RL: Cytokine production at the site of disease in human tuberculosis. Infect Immun 1993, 61:3482-3489.
18. Mosmann TR, Coffman RL: THI and TH2 cells: different patterns of lymphokine secretion lead to different functional properties. Annu Rev Immunol 1989, 7: 145-173.

19. Tanaka S, Sato M, Onitsuka T, Kamata H, Yokomizo Y: Inflammatory cytokine gene expression in different types of granulomatous lesions during asymptomatic stages of bovine paratuberculosis. Vet Pathol 2005, 42:579-588.

20. Langelaar MF, Weber CN, Overdijk MB, $M^{3}$ Iler KE, Koets AP, Rutten VP: Cytokine gene expression profiles of bovine dendritic cells after interaction with Mycobacterium avium ssp. paratuberculosis (M.a.p.), Escherichia coli (E. coli) or recombinant M.a.p. heat shock protein 70. Vet Immunol Immunopathol 2005, 107:|53-|6|.

21. Coussens PM, Verman N, Coussens MA, Elftman MD, McNulty AM: Cytokine gene expression in peripheral blood mononuclear cells and tissues of cattle infected with Mycobacterium avium subsp. paratuberculosis: evidence for an inherent proinflammatory gene expression pattern. Infect Immun 2004, 72: $1409-1422$.

22. Khalifeh MS, Stabel JR: Upregulation of transforming growth factor-beta and interleukin- 10 in cows with clinical Johne's disease. Vet Immunol Immunopathol 2004, 99:39-46.

23. Lee $\mathrm{H}$, Stabel IR, Kehrli ME: Cytokine gene expression in ileal tissues of cattle infected with Mycobacterium paratuberculosis. Vet Immunol Immunopathol 200I, 82:73-85.

24. Aho AD, McNulty AM, Coussens PM: Enhanced expression of interleukin- I alpha and tumor necrosis factor receptor-associated protein I in ileal tissues of cattle infected with Mycobacterium avium subsp. paratuberculosis. Infect Immun 2003 , 71:6479-6486.

25. North RJ, Jung YJ: Immunity to tuberculosis. Annu Rev Immunol 2004, 22:599-623.

26. Fitness J, Tosh K, Hill AV: Genetics of susceptibility to leprosy. Genes Immun 2002, 3:44I-453.

27. Rea TH, Modlin RL: Immunopathology of leprosy skin lesions. Semin Dermatol 1991, 10:188-193.

28. Myrvang B, Godal T, Ridley DS, Fr $\div$ land SS, Song YK: Immune responsiveness to Mycobacterium leprae and other mycobacterial antigens throughout the clinical and histopatholog. ical spectrum of leprosy. Clin Exp Immunol 1973, 14:54I-553.

29. Cocito C, Gilot P, Coene M, de Kesel M, Poupart P, Vannuffel P: Paratuberculosis. Clin Microbiol Rev 1994, 7:328-345.

30. Kurade NP, Tripathi BN, Rajukumar K, Parihar NS: Sequential development of histologic lesions and their relationship with bacterial isolation, fecal shedding, and immune responses during progressive stages of experimental infection of lambs with Mycobacterium avium subsp. paratuberculosis. Vet Pathol 2004, 41 :378-387.

31. Gonzales J, Geijo MV, Garcia-Pariente C, Verna A, Corpa JM, Reyes LE, Ferreras MC, Juste RA, Garcia M JF, Perez V: Histopathological classification of lesions associated with natural paratuberculosis infection in cattle. J Comp Pathol 2005, 133:184-196.

32. Flynn JL, Chan J: Immunology of tuberculosis. Annu Rev Immunol 2001, 19:93-129.

33. Libraty DH, Airan LE, Uyemura K, Jullien D, Spellberg B, Rea TH, Modlin RL: Interferon-gamma differentially regulates interleukin- 12 and interleukin- 10 production in leprosy. J Clin Invest 1997, 99:336-34|

34. Modlin RL: ThI-Th2 paradigm: insights from leprosy. J Invest Dermatol 1994, 102:828-832.

35. Dinarello CA: IL-I 8: A THI-inducing, proinflammatory cytokine and new member of the IL-I family. J Allergy Clin Immunol 1999, 103:II-24.

36. Becker C, Fantini MC, Neurath MF: TGF-beta as a T cell regulator in colitis and colon cancer. Cytokine Growth Factor Rev 2006 17:97-106.

37. Alzuherri HM, Woodall C], Clarke Cl: Increased intestinal TNF[alpha], IL-I [beta] and IL-6 expression in ovine paratuberculosis. Veterinary Immunology and Immunopathology 1996, 49:33I-345.

38. Elliott SN, Wallace JL: Neutrophil-mediated gastrointestinal injury. Can J Gastroenterol 1998, I 2:559-568.

39. Coussens PM: Model for immune responses to Mycobacterium avium subspecies paratuberculosis in cattle. Infect Immun 2004, 72:3089-3096.

40. Green EP, Tizard ML, Moss MT, Thompson J, Winterbourne DJ, McFadden JJ, Hermon-Taylor J: Sequence and characteristics of 
IS900, an insertion element identified in a human Crohn's disease isolate of Mycobacterium paratuberculosis. Nucleic Acids Res 1989, 17:9063-9073.

4I. Eishi Y, Suga M, Ishige I, Kobayashi D, Yamada T, Takemura T, Takizawa T, Koike M, Kudoh S, Costabel U, Guzman J, Rizzato G, Gambacorta M, du Bois R, Nicholson AG, Sharma OP, Ando M: Quantitative analysis of mycobacterial and propionibacterial DNA in lymph nodes of Japanese and European patients with sarcoidosis. J Clin Microbiol 2002, 40: 198-204.

42. Primer3 2007 [http://frodo.wi.mit.edu/cgi-bin/primer3/ primer3 www.cgi].

43. Blast 2007 [http://www.ncbi.nlm.nih.gov/blast/ Blast.cgi?CMD=Web\&PAGE TYPE=BlastHome].

44. Net Primer 2007 [http://www.premierbiosoft.com/netprimer/ index.html].

Publish with Bio Med Central and every scientist can read your work free of charge

"BioMed Central will be the most significant development for disseminating the results of biomedical research in our lifetime. "

Sir Paul Nurse, Cancer Research UK

Your research papers will be:

- available free of charge to the entire biomedical community

- peer reviewed and published immediately upon acceptance

- cited in PubMed and archived on PubMed Central

- yours - you keep the copyright 